\title{
Analysis of Temporal Drought Characteristic Using SPI Drought Index Based on Rainfall Data in Laikipia West Sub-County, Kenya
}

\author{
Amon Karanja, Kennedy Ondimu, Charles Recha \\ Department of Geography, Egerton University, Egerton, Kenya \\ Email: amon.karanja@egerton.ac.ke,kondimu@egerton.ac.ke, Charles.recha@egerton.ac.ke
}

How to cite this paper: Karanja, A., Ondimu, K. and Recha, C. (2017) Analysis of Temporal Drought Characteristic Using SPI Drought Index Based on Rainfall Data in Laikipia West Sub-County, Kenya. Open Access Library Journal, 4: e3765.

https://doi.org/10.4236/oalib.1103765

Received: June 25, 2017

Accepted: October 28, 2017

Published: October 31, 2017

Copyright $\odot 2017$ by authors and Open Access Library Inc.

This work is licensed under the Creative Commons Attribution International License (CC BY 4.0).

http://creativecommons.org/licenses/by/4.0/

\begin{abstract}
Severe drought has affected Kenya in the past decades reducing crop yields leaving millions of people in dire need of food. Drought cycle in Kenya has reduced increasing drought frequency in the recent decades. This study assessed drought characteristics in Laikipia West sub-County which lies in a region classified as arid and semi arid. The specific objective of the study was to analyze seasonal and annual drought characteristics in Laikipia West subCounty between 1984 and 2014. The study adopted documentary review design in the data collection. Standard Precipitation Index was used during the data analysis process. The drought years identified in Laikipia West subCounty were: 1984, 1985, 1987, 1991, 1995, 1999, 2000, 2005, 2008 and 2009. The seasonal drought events shows that for the period under study Laikipia West sub-County has never experience drought during the MAM and OND seasons in the same year. This explains the importance of seasonal climate forecast to crop farmers. The study also established that the average drought cycle in the study area is 3 years. The study recommends construction of mega water reservoirs which could collect water during the wet season to be utilized during the dry seasons. The study also recommends channeling of drought information through the government agencies at the beginning of every season.
\end{abstract}

\section{Subject Areas}

Atmospheric Sciences, Natural Geography

\section{Keywords}

Drought, Documentary Review, Drought Characteristics, Standard Precipitation Index, Drought Cycle 


\section{Introduction}

Drought is a form of environmental stress that originates from a deficiency in precipitation over an extended period of time long enough to cause moisture deficiency, biotic loss, crop failure, loss of lives both human and bovine and general hardships [1]. Drought is one of the critical natural disasters that adversely affect people, river basins, water resource systems and ecosystems [2]. Assessment of drought conditions is critical for planning water supplies, irrigation systems, crop and food security program, hydropower generation, water quality management and waste disposal systems [3].

El Niño events are associated with many global climatic anomalies such as flooding and drought [4]. Droughts in many parts of the world are part of normally occurring inter-annual climate variations, and although El Niño events may cause or intensify drought conditions, many droughts are independent of the El Niño phenomena. This variable as a cause of drought is exemplified in southern Africa, where there is a strong correlation between the El Niño and rainfall patterns [5], but not all droughts are correlated to El Niño events and conversely not all El Niño events result in drought conditions. According to [6] inter-annual climate variability (El Niño) has huge impacts on the region's climate. Warm El Niño events produce abnormally high amounts of precipitation in parts of equatorial Africa. It has been documented that in Sub-Saharan Africa, eight major droughts have occurred in the last four decades: 1965/66, 1972/74, 1981/84, 1986/87, 1991/92, 1994/95, 1999/2001 and 2005/06 [7]. According to [8] East Africa has been faced by large variability in rainfall with occurrence of extreme events in terms of droughts and floods. The region has experienced droughts in the last 20 years-1983/84, 1991/92, 1995/96, 1999/2001, 2004/2005. El-Niño related floods of 1997/98 were a very severe event enhanced by unusual pattern of SST in the Indian Ocean. Africa will be affected more severely by drought than other regions [9].

Between the early 1970s and the mid 1990s the African Sahel experienced one of the most dramatic long-term changes in climate observed anywhere in the world in the twentieth century, with rainfall declining on average by more than twenty percent [10]. Drying trends have also been observed in the northern Congo basin, and may continue, resulting in a transition to savannah in this region [11]. Over the past 50 years, Kenya has experienced at least one main drought per decade [12]. The severity and frequency of droughts in Kenya have been increasing over the years. Drought was chosen because it has been a major threat to households' livelihoods in Kenya in the last 30 years [13].

\section{Materials and Methods}

\subsection{Study Area and Research Methodology}

The study area was Laikipia West sub-County in Laikipia County, Kenya. The choice of Laikipia West sub-County was based on variation in livelihood options. Drought impacts and adaptations strategies are determined by economic 
activities of the households and their variations leads to adoption of different adaptation strategies. Laikipiameans treeless plain in Maasai language [14]. Laikipia West sub-County is located to the north west of Mount Kenya. The sub-County lies between Latitude $0^{\circ} 05^{\prime}$ and $0^{\circ} 43^{\prime}$ North and between longitudes $36^{\circ} 10^{\prime}$ and $36^{\circ} 50^{\prime}$ East and an area of $3188.8 \mathrm{Km}^{2}$ as shown in Figure 1. The altitude of the Sub-County varies between $1000 \mathrm{~m}$ above sea level and $2600 \mathrm{~m}$ [15]. Laikipia West sub-County has four administrative wards namely; Rumuruti, Muhotetu, Sipili and Olmoran [16].

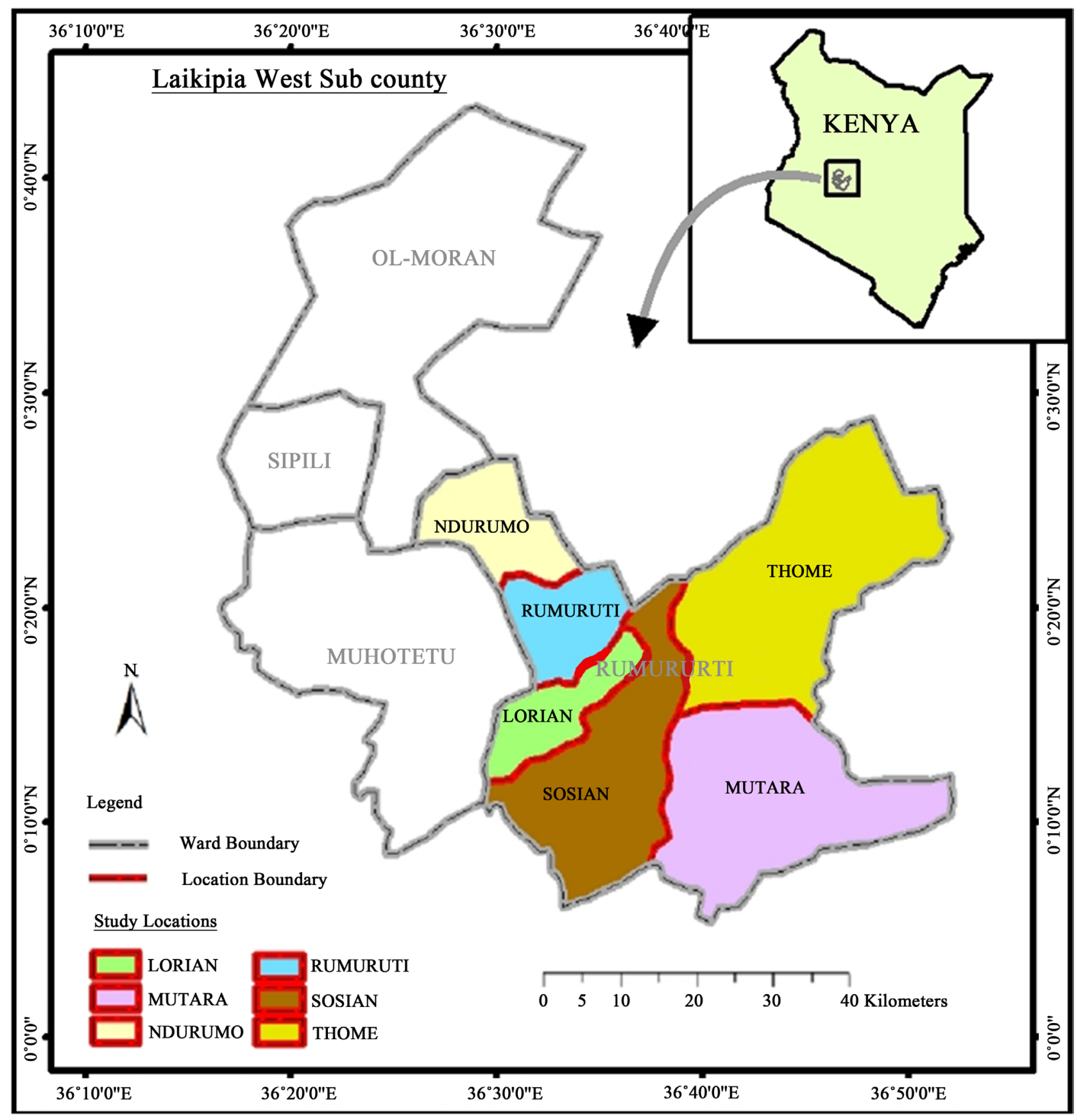

Figure 1. A map of Laikipia west sub-county showing the sampled sites. Source: [20]. 


\subsection{Climate and Agro-Ecological Zones}

The study area is located in the rain shadow of Mount Kenya making the area dry. The sub-County has humid, semi humid and semi-arid agro-ecological zones. The agro ecological zone of Rumuruti ward the sampled ward is $\mathrm{LH} 4, \mathrm{LH}$ 5 and UM 5 [17]. Laikipia West sub-County is classified as $50 \%-85 \%$ ASAL with an annual rainfall varying between 500 and $800 \mathrm{~mm}$ [18]. Daily temperatures vary with altitude and season; mean temperatures range within $22^{\circ} \mathrm{C}$ $26^{\circ} \mathrm{C}$ and temperature Minimum and Maximum are $6^{\circ} \mathrm{C}-14^{\circ} \mathrm{C}$ and $35^{\circ} \mathrm{C}$ respectively. Due to the sub-County leeward position North West of Mount Kenya, it is comparatively dry despite its location on the Equator. The spatial distribution and the temporal viability of rainfall are strongly influenced by Mount Kenya and Aberdare Ranges. Rainfall follows the seasonal movements of the Inter Tropical Convergence Zone (ITCZ) resulting in two rainfall seasons [19]. The rains primarily fall in two seasons; first is the wet season that occurs during March-April-May and often accounting for $80 \%$ of total annual rainfall. Second is the wet season that occurs in October-November-December.

Rainfall amount data for a period of 31 years (1984 to 2014) was utilized. Thirty one year's period was chosen because it is within the minimum period which climate change is believed to take place. In 1984 Kenya experienced among the worst droughts in history while 2014 severe drought predicted. This necessitated the study on drought characteristics and trends between the two inter drought periods in Laikipia West sub-County. Rainfall data was collected from Rumuruti and Ndaragwa WRMA stations. The selection of the stations was informed by the fact that they are the only reliable stations in the study area. Although there are other weather stations such Mukogondo forest and Nyahururu rainfall stations in Laikipia West sub-County, the data collected from these stations was not considered for the analysis because more than $34 \%$ of the data was missing and failed the reliability of climatological test.

Standardized precipitation index (SPI) was used in the analysis of drought characteristics. Standardized Precipitation Index (SPI) expresses the actual rainfall as a standardized departure with respect to rainfall probability distribution function and hence the index has gained importance in recent years as a potential drought indicator permitting comparisons across space and time [21]. The computation of SPI requires long term data on precipitation to determine the probability distribution function which is then transformed to a normal distribution with mean zero and standard deviation of one. Thus, the values of SPI are expressed in standard deviations, positive SPI indicating greater than median precipitation and negative values indicating less than median precipitation [22]. Drought characteristics analyzed were; drought frequency, drought severity and drought magnitude. Positive SPI values indicate greater than median precipitation and negative value indicate less than median precipitation because the SPI is normalized. Wetter and drier climates are represented in the same way; thus wet and dry periods are monitored using SPI as on Table 1 . Time series was used to analyze rainfall trends. 
Table 1. SPI values.

\begin{tabular}{cc}
$2.0+$ & Extremely wet \\
1.5 to 1.99 & Very wet \\
1.0 to 1.49 & Moderately wet \\
-0.99 to 0.99 & Near normal \\
-1.0 to -1.49 & Moderate dry \\
-1.5 to -1.99 & Severely dry \\
-2 and less & Extremely dry \\
\hline
\end{tabular}

Source: WMO (2012).

\section{Results and Discussions}

\subsection{Rainfall Trend in Laikipia West Sub-County (1984-2014)}

Rainfall trend is the graphical representation of the observed drought years from 1984 to 2014 in Laikipia West sub-County. Results in Figure 2(a) and Figure 2(b) show the trend on rainfall amounts in Ndaragwa and Rumuruti stations. The highest rainfall amount was experienced in 1997 and 1998 in Rumuruti and Ndaragwa respectively. This coincides with the 1997/1998 El Niño phenomena in Kenya where the country received rainfall above normal. Other periods when the region experienced high rainfalls are 1990 and 2012. The lowest average rainfall was experienced in 1984, 1999, 2000 and 2009. When compared to the mean rainfall, $53 \%$ of the study period in Rumuruti station received below mean rainfall while $40 \%$ received rainfall above the mean. This shows that during the study period more years recorded below normal rainfall.

The lowest average rainfall experienced in 1999 and 2000 coincides with the La Niña phenomena that followed the El Niño rains of 1997 and 1998. In a related study, it was established that in South Africa drought disasters tend to occur in the year following the onset of El Niño and are less frequent at other times [23]. The lowest rainfall amount was recorded in 1984 in Rumuruti and in 2009 in Ndaragwa stations. Ndaragwa has had a higher precipitation compared to Rumuruti and this could be due to its proximity to the Aberdare Ranges. Results rainfall trend are similar to the findings of [24] in the Sahel region, and [25] in Tharaka, Kenya, who established a return to normal rainfall pattern after a depressed rainfall pattern in the early 1980s.

When compared to the mean rainfall, $47 \%$ of the study period in Ndaragwa station received below the mean rainfall while $37 \%$ received rainfall above the mean. This shows that during the study period more years recorded below normal rainfall as compared to the years that received above normal rainfall. During the study period only $16 \%$ of the years received normal rainfall in Ndaragwa. The mean rainfall in Ndaragwa station is higher compared to Rumuruti station and this could mean that Mutara location which is in proximity to Ndaragwa could have favourable conditions to support maize (other crop) farming or growth of pasture than the other Locations in Rumuruti Ward. 


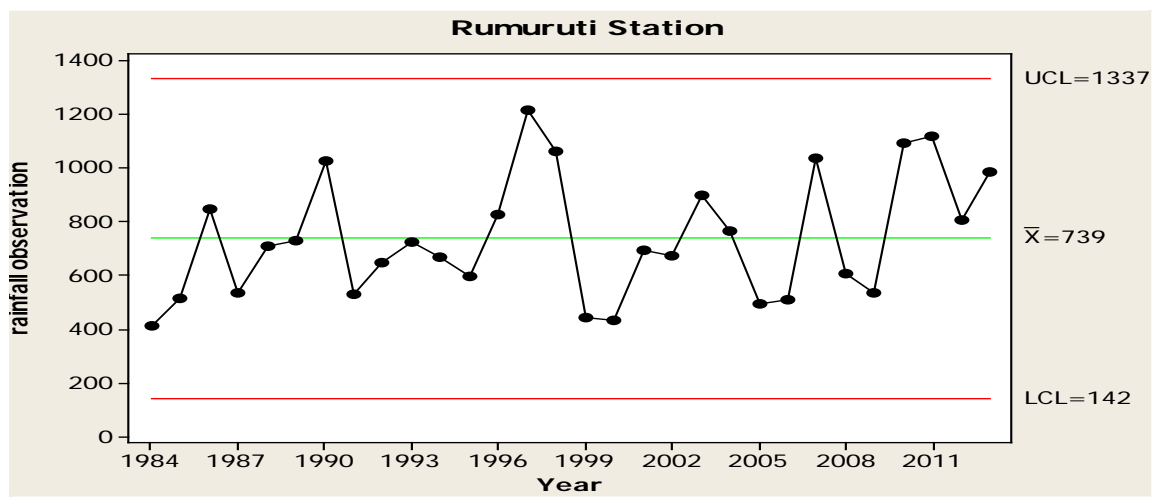

(a)

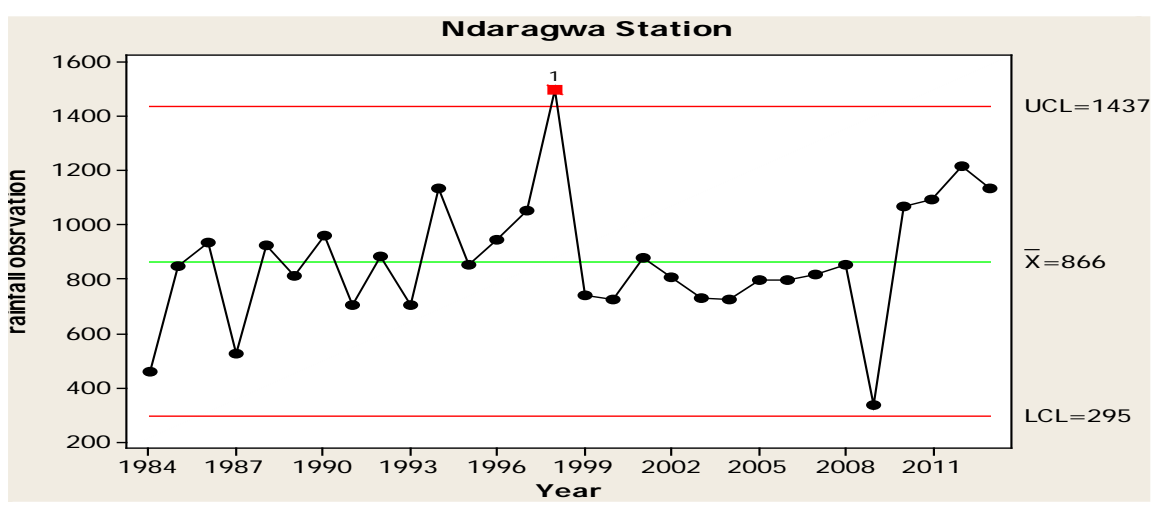

(b)

Figure 2. (a) Annual rainfall trend (1984-2014) for Rumuruti station; (b) Annual rainfall trend (1984-2014) for Ndaragwa station. Source: Field data (2016).

\subsection{Drought Characteristics in Laikipia West Sub-County (1984-2014)}

Rainfall amount data was used to identify, quantify and classify seasonal drought years, both long and short rain seasons in Laikipia West sub-County from 1984 to 2014. Drought characteristics have been analyzed on seasonal and annual bases. Drought analysis during the wet months has been necessitated by the importance of the seasons to crop growers in the study site who entirely depend on rain fed agriculture. The wet months in Laikipia West sub-County are March, April and May (MAM) which is a long rain season and October, November and December (OND) which is a short rain season. The dry months are January, February, June, July, August and September. In this study, drought was categorized as moderate, severe and extreme. Moderate drought refers to the drought with the SPI value of -1.0 to -1.49 . Severe drought refers to drought with SPI value of -1.5 to -1.99 and extreme drought refers to drought with SPI value of -2 .

Results in Figure 3 show that for the period under study during the long rain season, about $19 \%$ and $16 \%$ of the years received below normal rainfall at $\mathrm{Ru}$ muruti and Ndaragwa stations respectively. It is notable that; 1993 and 2000 were the driest years during the MAM at both Rumuruti and Ndaragwa; while 1998 was the wettest year in both stations during the same season. The recent 


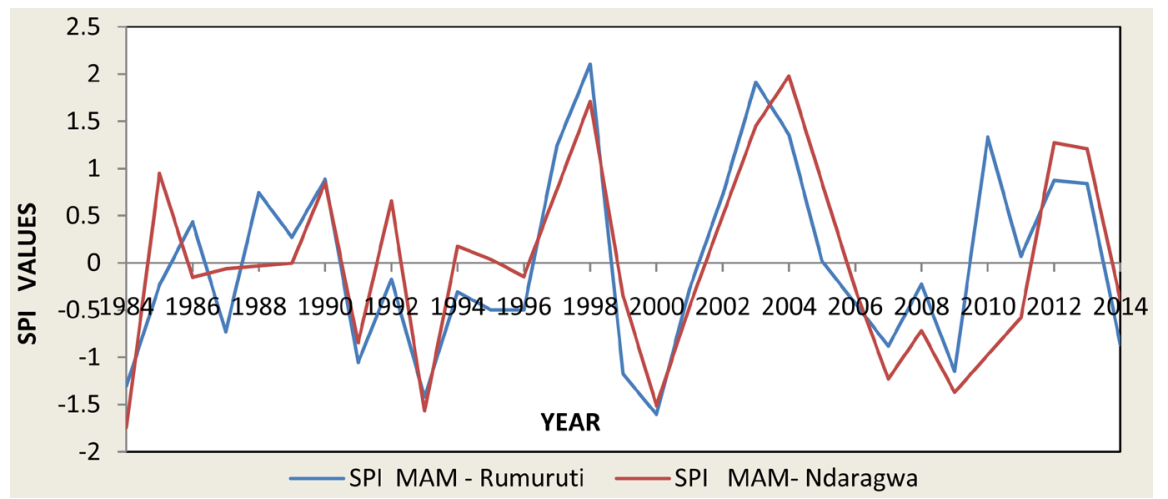

Figure 3. Long rain season SPI results for rumuruti and Ndaragwa station. Source: Field data (2016).

drought during MAM was in 2009 in Ndaragwa and Rumuruti stations. The SPI results in Figure 4 show that for the period under study, about $16 \%$ and $29 \%$ of the years received below normal rainfall during the OND at Rumuruti and Ndaragwa stations respectively. It is notable that; 1985, 1987, 1996 and 2010 were the driest years at both Rumuruti and Ndaragwa; while 1997 was the wettest year in both stations during the same seasons. The recent drought during OND was in 2010 in Ndaragwa and Rumuruti stations.

The seasonal drought events shows that for the period under study Laikipia West sub-County has never experience drought during the MAM and OND seasons in the same year. This shows that in case there is drought in one season the following season is a non drought season. This explains the importance of seasonal climate forecast to crop farmers on placing the best bet in maximizing production in favourable seasons and to caution them during unfavorable seasons either by planting drought resistant seeds or opting not to cultivate crops. The findings supports the earlier argument by [26] that revealed that in United State of America poor temporal spread of rainfall is harmful to crop. The findings also supports the earlier argument by [27] that regular occurrence of drought as a result of erratic rainfall distribution and cessation of rain during the growing season reduced Nigeria's capability for increased crop production.

The annual drought analysis is important because of the livestock farmers who depend entirely on natural pasture for their livestock throughout the year. The standard precipitation index annual results in Figure 5 show that for the period under study, about $36 \%$ and $17 \%$ of the years received below normal annual rainfall at Rumuruti and Ndaragwa stations respectively. Also 40\% and 67\% of the total number of years under study received normal rainfall at Rumuruti and Ndaragwa stations respectively. It is notable that: 1984, 1987 and 2009 were the driest years at both Rumuruti and Ndaragwa; while 1998 was the wettest year in both stations. These findings highlight the significance of global scale drivers of climatology such as ENSO and regional scale drivers of climatology such ITCZ on East African climate. It is instructive to note that in 1990, Rumuruti received above normal rainfall while Ndaragwa received below normal rainfall. 


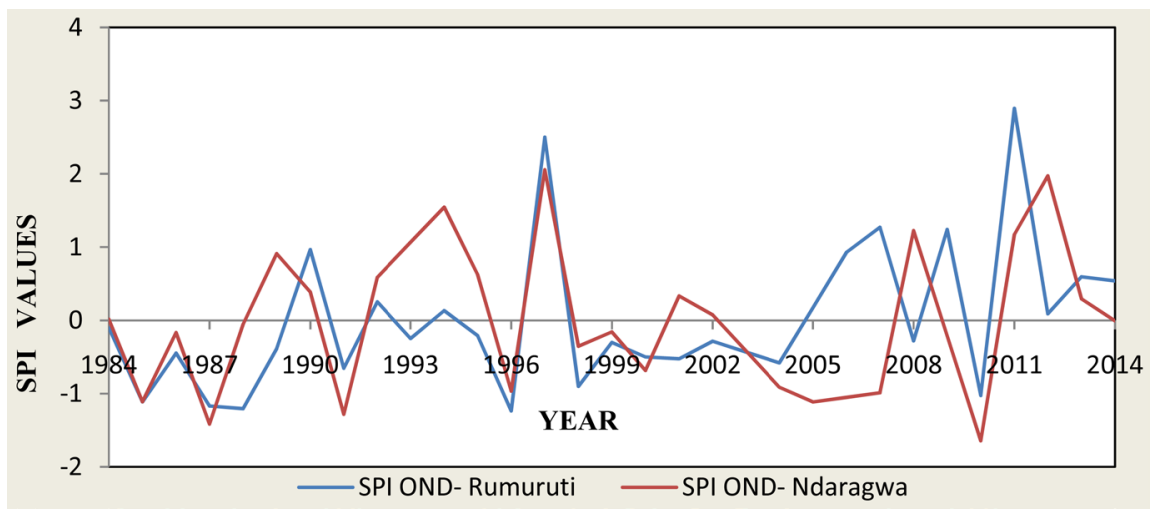

Figure 4. Short rain SPI results for Rumuruti and Ndaragwa station. Source: Field data (2016).

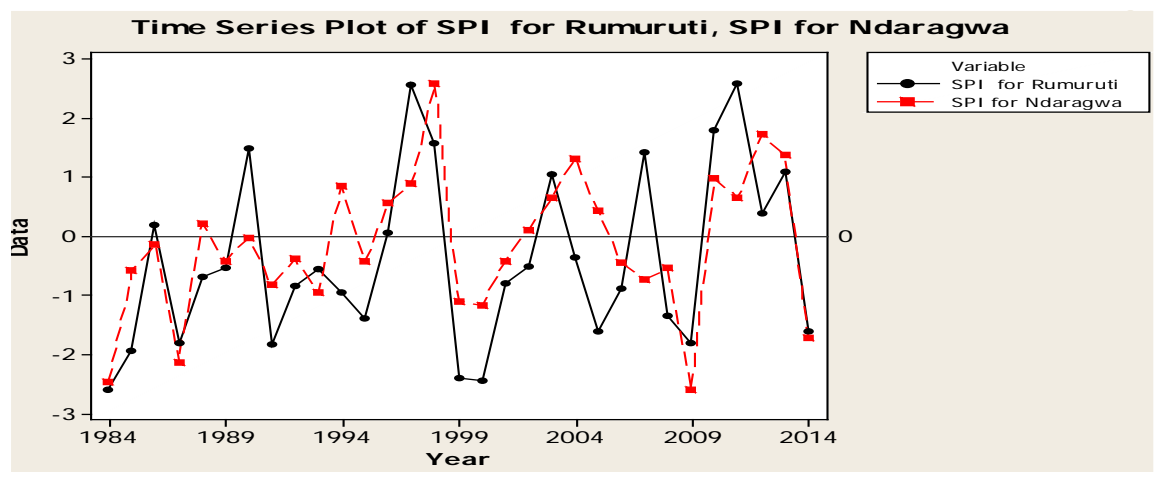

Figure 5. Annual SPI results for Rumuruti and Ndaragwa station. Source: Field data (2016).

The results highlight the significance of localized factors such vegetation cover and topography in influencing rainfall amount. Notable too is establishment that Rumuruti station has experienced more droughts in the past than Ndaragwa station.

The results presented in Figure 5 reveal that, moderate drought was experienced in 1995 and 2008 in Rumuruti and 1999 and 2000 in Ndaragwa; severe drought in 1985, 1987, 1991, 2005, 2009 and 2014 at Rumuruti station and 2014 in Ndaragwa; while extreme drought was experienced in 1984, 1999 and 2000 in Rumuruti and 1984, 1987 and 2009 in Ndaragwa. The 1984 drought is on record as the most severe drought in Kenya that was triggered by La Niña event of 1982-1984 [28]. The wet years are also classified as moderately wet, very wet and extremely wet years. These are quantified as 1.0 to $1.49,1.5$ to 1.99 , and 2.0 and above respectively. The moderately wet (1.0 to 1.49) years were: 1990, 2003, 2007 and 2013 in Rumuruti and 2004, 2010 and 2013 in Ndaragwa.

These results concur with earlier studies that the drought cycle has changed in the recent time and become more frequent, 2 - 3 years, giving no time to recover from the effects [29] [30] [31]). The wet years (1.5 to 1.99) were 1998 and 2010 in Rumuruti and 2012 in Ndaragwa. The extreme wet years ( 2.0 and above) were 1997 and 2011 in Rumuruti and 1998 in Ndaragwa. Other regions of the world 
that experienced drought during the same period include Thailand [32] and South Africa [33] [34] [35] [36].

\section{Conclusion and Recommendation}

There has been an increasing trend on average rainfall amount in Laikipia West sub-County. The years that received below normal rainfall (drought years) (-0.99 to 0.99) were: 1984, 1985, 1987, 1991, 1995, 1999, 2000, 2005, 2008, 2009 and 2014. The recent extreme drought event in Laikipia West sub-County was experienced in 2009. The near normal rainfall ( -0.99 to 0.99$)$ years were: 1986 , 1988, 1989, 1992, 1993, 1994, 1996, 2001, 2002, 2004, 2006 and 2012. The above normal rainfall (Wet years) were: 1990, 1997, 1998, 2003, 2007, 2010, 2011 and 2013. The highest amount of Laikipia West sub-County was experienced in 1997 and 1998 and this was during the El Nino phenomena where Kenya as Country received rainfall above normal. The seasonal drought events shows that for the period under study Laikipia West sub-County has never experience drought during the MAM and OND seasons in the same year. This explains the importance of seasonal climate forecast to crop farmers. The study recommends construction of mega water reservoirs that will collects water during the rainy seasons and this water could be utilized during the dry periods for both domestic and irrigation use. Since the demand for horticulture product is high during dry periods the collected water can be utilized during drought as an opportunity to make wealth in Laikipia West sub-County. The study also recommends channeling of drought information through the government agencies at the beginning of every season.

\section{Acknowledgements}

The authors of this article acknowledge the Egerton University, Division of Research and Extension for availing funds to support in publication of the article from the on-going research on effects drought on household livelihoods and adaptation strategies in Laikipia West sub-County, Kenya. The authors acknowledge the immense help received from the scholars whose articles are cited and included in references of this manuscript. The authors are also grateful to authors, editors and publishers of journals and books from where the literature of this article has been referred.

\section{References}

[1] Ngaira, J.K. (2004) Basic Facts in Contemporary Climatology. Lake Publishers and Enterprises, Kisumu.

[2] Jahangir, A.T.M., Sayedur, R.M. and Saadat, A.H.M. (2013) Monitoring Meteorological and Agricultural Drought Dynamics in Barind Region, Bangladesh Using SPI and Markov Chain Model. International Journal of Geomatics and Geosciences, 3, 511-524.

[3] Abad, M.B.J., Zade, A.H., Rohina, A., Delbalkish, H. and Mohagher, S.S. (2013) The Effect of Climate Change on Flow Regime in Basher River Using Two Meteorologi- 
cal and Hydrological Standards. International Journal of Agriculture and Crop Sciences, 5, 2852-2857.

[4] Glynn, P.W., Ed. (1990) Global Ecological Consequences of the 1982-83 El-NinoSouthern Oscillation.

[5] Wright, P.B. (1977) The Southern Oscillation: Patterns and Mechanisms of the Teleconnections and the Persistence. Report HIG-77-13 of Hawaii Institute of Geophysics. University of Hawaii Press.

[6] Muga, M. (2010) Climate Change: A Major Challenge and Revelation for EA Nationals. A Journal on Resource, Reflection and Discourse for Sustainable Development, 32, 201-207.

[7] Nikola, R. (2006) Policies and Strategies to Address the Vulnerability of Pastoralists in Sub-Saharan Africa. http://www.fao.org/ag/pplpi.html

[8] IPCC (2007) Climate Change 2007: The Physical Science Basis, Contribution of Working Group to the Fourth Assessment Report of the Intergovernmental Panel on Climate Change. In: Solomon, S., Qin, D., Manning, M., Chen, Z., Margiquis, M., Averyt, K.B., Tignor, M. and Miller, H.L. Eds., Cambridge University Press, Cambridge and New York, 996 p.

[9] Yanda, P.Z. and Mubaya, C.P. (2011) Managing a Changing Climate in Africs; Local Level Vunerabilities and Adaptation Eperiences, Dar es Salaam, Mkuki na Nyota

[10] Hulme, M., Doherty, R., Ngara, T., New, M. and Lister, D. (2001) African Climate Change: 1900-2100. Climate Research, 17, 145-168. https://doi.org/10.3354/cr017145

[11] Warren, R. (2006) Impacts of Global Climate Change at Different Annual Mean Global Temperature Increases. In: Schellnhuber, H.J., Cramer, W., Nakicenovic, N., Wigley, T. and Yohe, Eds., Avoiding Dangerous Climate Change, Cambridge University Press.

[12] FAOSTAT (2000) Aquastat Land Use Database. FAO, Rome.

[13] Huho, J.M. and Kosonei, R.C. (2013) The Opportunities and Challenges for Mitigating Climate Change through Drought Adaptive Strategies: The Case of Laikipia County, Kenya. Journal of Social Sciences and Humanities, 2223-9944.

[14] CDIDP (2013) First County Development Integrated Development Plan (20132017) Laikipia County.

[15] Thenya, T., Kiteme, B.P., Ouko, C.A., Kahiu, N., Njuguna, E.C., Karanja, F., Ojwang, D. and Wambugu, G, (2011) Assessment of Ecological Status and Socio-Economic Dynamic of Upper Ewaso Ng'iro Basin Wetlands. CETRAD.

[16] KNBS (2010) Kenya Population and Housing Census Volume 1(A) Ministry of Planning and Vision 2030. Government Printers, Nairobi.

[17] Jaetzold, R., Schmidt, H., Hornetz, B. and Shisanya, C. (2011) Farm Management Handbook of Kenya Vol. 11 Natural Conditions and Farm Management Information. 2nd Edition Part B Central Kenya Subpart B1b Northern Rift Valley Province. Ministry of Agriculture, Nairobi.

[18] Government of Kenya (2010) National Climate Change Response Strategy. Ministry of Environment and Mineral Resources, Nairobi.

[19] Huho, J.M., Ngaira, J.K. and Ogindo, H.O. (2010) Drought Severity and Their Effects on Rural Livelihoods in Laikipia District, Kenya. Maseno University. Journal of Geography and Regional Planning, 3, 35-43.

[20] IEBC (Independent Electoral and Boundaries Commission) (2012) Electoral Boundaries in Kenya. Kenya Government. 
[21] Kumar, M.N., Murthy, C.S., Sesha, M.V.R. and Roy, P.S. (2010) The Use of Standardized Precipitation Index (SPI) for Drought Intensity Assessment. National Remote Sensing Centre, Hyderabad 500625.

[22] Edwards, D.C. and McKee, T.B. (1997) Characteristics of 20th Century Drought in the United States at Multiple Time Scales. Climatology Report 97-2, Department of Atmospheric Science, Colorado State University, Fort Collins.

[23] Dilley, M. and Heyman, B.N. (1995) ENSO and Disaster: Droughts, Floods and El Niño/Southern Oscillation Warm Events. Disasters, 19, 181-193. https://doi.org/10.1111/j.1467-7717.1995.tb00338.x

[24] Anyamba, A. and Tucker, C.J. (2005) Analysis of Sahelian Vegetation Dynamics using NOAA-A-AVHRR NDVI Data from 1981-2003. Journal of Arid Environment, 63, 596-614.

[25] Recha, C.W., Makokha, G.L., Traore, P.S., Shisanya, C., Lodoun, T. and Sako, A. (2012) Determination of Seasonal Rainfall Variability, Onset and Cessation in Semi-Arid Tharaka District, Kenya. Theoretical and Applied Climatology, 108, 479-494. https://doi.org/10.1007/s00704-011-0544-3

[26] Boubacar, I. (2012) The Effects of Drought on Crop Yields and Yield Variability: An Economic Assessment. International Journal of Economics and Finance, 4. https://doi.org/10.5539/ijef.v4n12p51

[27] Olaoye, O. (1999) Developing Drought Tolerant Varieties for the Savanna AgroEcologies of Nigeria in 25th Year Commemoratives Publications of Genesis Society of Nigeria. 173-182.

[28] Shisanya, C.A. (1990) The 1983-1984 Droughts in Kenya. Journal of Eastern African Research and Development, 20, 127-148.

[29] Aklilu, A. and Alebachew, A. (2009) Assessment of Climate Change-Induced Hazards, Impacts and Responses in the Southern Lowlands of Ethiopia. FSS Research, Report No. 4, FSS, Addis Ababa.

[30] Coppock, D.L. (1994) The Borena Plateau of Southern Ethiopia: Synthesis of Pastoral Research, Development, and Change, 1980-1990. System Study No. 5. International Livestock Centers for Africa, Addis Ababa, 374 p.

[31] Anderson, S. and Mowjee, T. (2008) Climate Change for Agrarian Societies in Dry Lands Implications and Future Path Ways' Presentation for the World Bank Social Development Division Conference on the Human Dimensions of Climate Change.

[32] Prapertchob, P., Bhandari, H. and Pandy, S. (2007) Economic Cost of Drought and Rice Farmers' Coping Mechanisms in Northeast Thailand. In: Pandey, S., Bhandari, H. and Hardy, B., Eds., Economic Costs of Drought and Rice Farmers Coping Mechanisms: A Cross-Country Comparative Analysis, IRRI, Los Baños, 113-148.

[33] Tyson, P.D. and Dyer, T.G.J. (1978) The Predicted Above-Normal Rainfall of the Seventies and the Likelihood of Droughts in the Eighties in South Africa. South African Journal of Science, 74, 372-377.

[34] Vogel, C. (2000) Usable Science: An Assessment of Long-Term Seasonal Forecasts among Farmers in Rural Areas of South Africa. South African Geographical Journal, 82, 107-116. https://doi.org/10.1080/03736245.2000.9713700

[35] Adger, W.N. (2001) Scales of Governance and Environmental Justice for Adaptation and Mitigation of Climate Change. Journal of International Development, 13, 921-931. https://doi.org/10.1002/jid.833

[36] Kihupi, N., Kingamkono, R., Dihenga, H., Kingamkono, M. and Rwamugira, W. (2003) Integrating Indigenous Knowledge and Climate Forecasts in Tanzania. 
Submit or recommend next manuscript to OALib Journal and we will provide best service for you:

- Publication frequency: Monthly

- 9 subject areas of science, technology and medicine

- Fair and rigorous peer-review system

- Fast publication process

- Article promotion in various social networking sites (LinkedIn, Facebook, Twitter, etc.)

- Maximum dissemination of your research work

Submit Your Paper Online: Click Here to Submit

Or Contact service@oalib.com 